\title{
Implementation and Evaluation of Accounting Information Systems in Manufacturing Company Using System Usability Scale
}

\author{
I. M. S. Sandhiyasa ${ }^{1}$, C. P. Yanti ${ }^{2}$, Theresia Hendrawati ${ }^{3}$ \\ ${ }^{1,2.3}$ Informatics Department, STMIK STIKOM Indonesia \\ Denpasar - Bali, Indonesia \\ subrata.sandhiyasa@stiki-indonesia.ac.id
}

\begin{abstract}
Information systems can facilitate business actors to control and evaluate business reporting effectively and efficiently. Anugrah Sri Jaya is a business engaged in manufacturing. This company still uses a manual recording system which causes several problems, namely frequent errors in calculations and mismatch of inventory stock records with actual conditions. Therefore, the researcher proposes to implement an information system in the accounting process at Anugrah Sri Jaya. From the results of the study, researchers have succeeded in building a web-based accounting information system at Anugrah Srijaya. Information system testing uses the System Usability Scale (SUS) method where the test uses a questionnaire as an assessor and the number of responses is 5 respondents where the respondents from this study are business owners and several employees who will later use this system. From the results of the tests carried out, it can be seen that the average score obtained from the calculation of the System Usability Scale (SUS) is 74.5. Based on the results of the average score, this system can be said to be in the category of acceptance (Acceptable) and on the adjective rating scale, the information system built is rated as excellent.
\end{abstract}

Index Terms - Information System; Accountancy; System Usability Scale; Financial Statements; Manufacture

Note: There should no nonstandard abbreviations, acknowledgments of support, references or footnotes in in the abstract.

\section{INTRODUCTION}

The search for information is now made easier with the existence of technology. The phenomenon of technological development occurs in various aspects such as government, academic, or banking [1]. Competition between businesses that is happening at this time is getting tighter where the growing business is required to further improve the quality and quality of services and data accuracy. A business must have accurate, timely and relevant information [2].

The information system is a system within an organization that brings together the needs of processing, daily transactions, as a support for managerial operations and providing reports needed by an organization [3]. Information systems can also make it easier for business actors to control and evaluate business processes and can control business reporting effectively and efficiently [4]. A good information system must be in accordance with the needs and business activities carried out by a business [5].
In running its business, company management requires information that can be presented according to its needs. Accounting is one way to produce information, especially company finances that can be used as a basis for making decisions [6].

Anugrah Sri Jaya is a company located at Jalan Raya Angggung, No. 40 Lukluk-Mengwi. This company is engaged in manufacturing in the form of making steel roofs, canopies, gutters and others. Currently, the process of recording and managing transaction data at Anugrah Sri Jaya applies conventional business processes where transaction data is recorded in the form of a daily journal, then processed in the accounting process by handwriting and making financial reports using the Microsoft excel application. Based on the results of an interview by I Wayan Indra Sastrawan as a business voter, in the calculation of terms of sale (receivables) often miscalculations occur due to the number of total transactions each day, namely 10 project-based transactions so that delays and errors in collecting receivables from customers often occur. In addition, the problem that often occurs is cash receipts for employees, so that often the recording of cash payments is 
not in accordance with what it should be. Another problem also occurs in the raw material inventory data which is not in accordance with the reality where it affects the company's profit. All of the above problems also have an impact on the quality of the company's financial statements that are needed by business owners in making policies to advance their business. Based on these problems, the application of accounting information systems in companies is very important [7].

\section{Procedures For Paper SUbMisSion}

\section{A. Review Stage}

This study uses the waterfall method in the development of information systems. The reason for using the waterfall method is because the waterfall method steps carried out in this method are carried out sequentially and continuously [8]. The stages of the waterfall method can be seen in Figure 1.

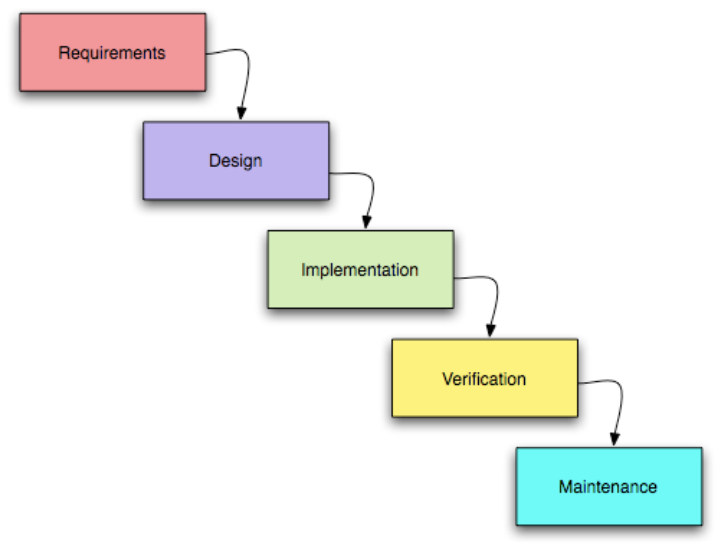

Fig. 1. Waterfall Method

The waterfall method begins with a needs analysis where this process collects data and determines what is needed by the company. After the needs analysis process, the next system design is carried out where this process carries out the design and design of the accounting information system to be built. The next step is the implementation process of the results of system design and design, namely coding or writing program code. After the system has been completed, the program is tested before being used in real terms. The next stage is the implementation of the maintenance program and process.

\section{1) Requirement}

In the system requirements analysis stage, it is carried out to describe user needs related to the information system to be developed [9]. In this process, data collection is carried out as material for system development. The method used in this process is the interview method by the owner of the company and observation or observation of the ongoing operational process by coming directly to the research site. In addition to conducting interviews and observations, the stage of needs analysis is also carried out by analyzing the functional requirements of the system. Functional requirements analysis is the determination of the features that users need in the system to be built [10].

\section{2) Design}

The system design must support the company's main objectives in accordance with the results of the needs analysis that has been done previously [11].

\section{Use Case Diagram}

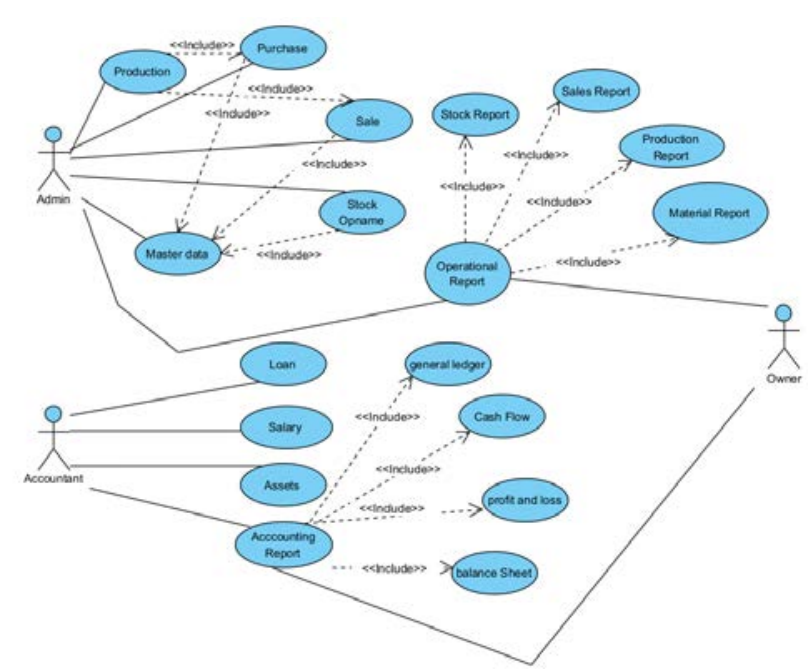

Fig. 2. Use Case Diagram

The use case diagram shows that the system has 3 users, namely admin, accountant and owner. Admin manages master data, stock taking, sales, purchases and production. Accountants manage employee cash receipts, employee payroll, asset data, and financial reports. While the owner can manage all processes that exist in the system.

\section{Database Design}

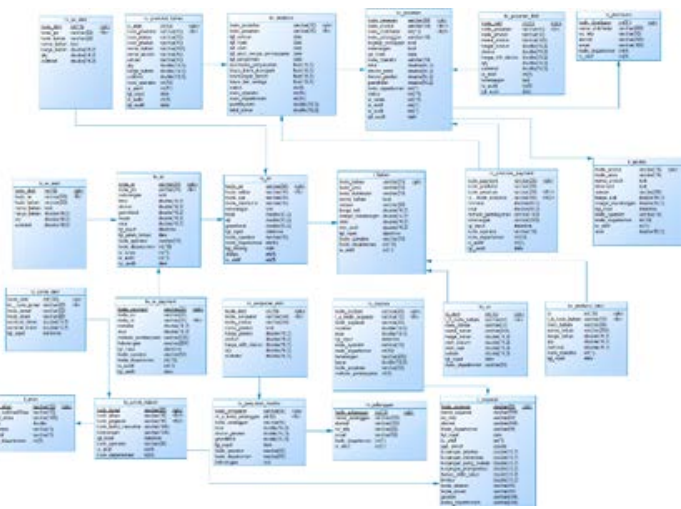

Fig. 3. Class Diagram

\section{3) Implementation}

After the system design process is complete, then implement the results of the design and design into 
programming form. This system uses the CodeIgniter (CI) framework with the PHP programming language. While the database used is MySQL. MySQL is a relational database system so that it can group data into groups or tables related to data [12]

\section{4) Verification}

Verification in this study using the System Usability Scale (SUS) method. System Usability Scale (SUS) testing is a method for assessing the usability of a product [13]. The characteristics of the System Usability Scale (SUS) that make it interesting and different from other questionnaires. The advantage of the System Usability Scale (SU)S is that this method consists of ten questions, making it relatively fast and easy for respondents to complete. Another advantage is that the System Usability Scale (SUS) using technology can be widely used and evaluates almost all types of interfaces, including websites, smartphones, interactive voice response (IVR), systems (touch-tone and speech), TV, etc. The questionnaire results from the System Usability Scale (SUS) are single scores, ranging from a score of 0 to 100 , and are relatively easy to understand by various disciplines, both individuals and groups [14].

\section{5) Maintenance}

In this process, the author seeks to develop a system that has been designed related to software and hardware so that the application can run well and according to needs.

\section{RESULTS}

\section{A. System Display}

\section{Home Page}

The following is a display of the system owner dashboard page. Contains a graphic display of information related to purchases, sales and accounting, so that company owners get information about which products are purchased the most or to distributors or which products are sold the most and even the company's total revenue and profit and loss are also displayed on the graph.

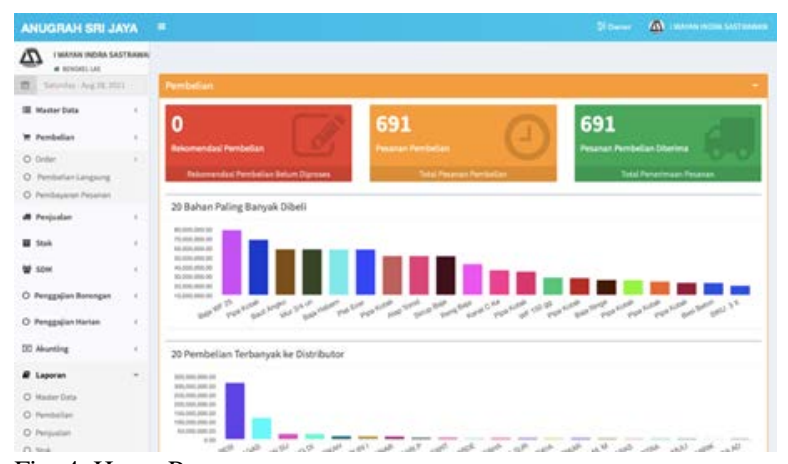

Fig. 4. Home Page

\section{Master Data Menu Page}

In the master data, there are seven data menus, namely Material Data, Product Data, Type Data, Customer Data,
Employee Data, Distributor Data and User Data. As an example of the display, the following display of material data is shown in Figure 5.

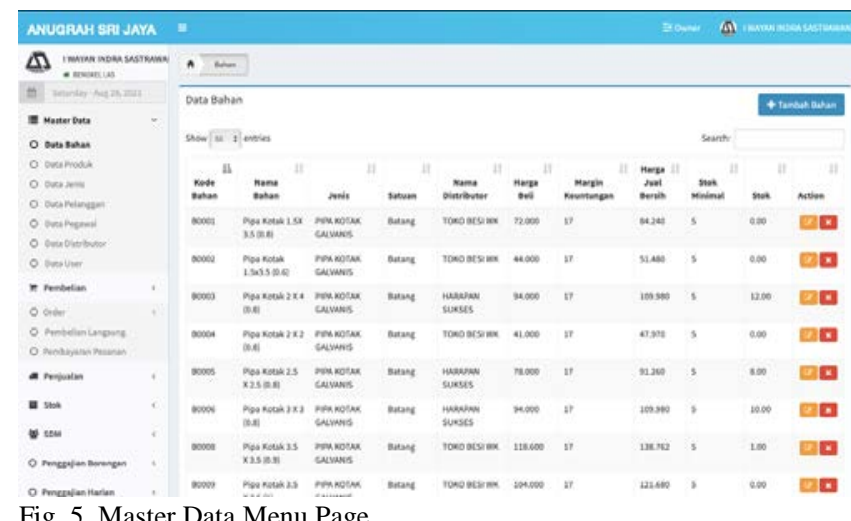

\section{Purchase Menu Page}

On the purchase menu, there are several sub-menus, namely the order menu, the direct purchase sub-menu and the order payment sub-menu. Here is one of the displays on the purchase menu in Figure 6.

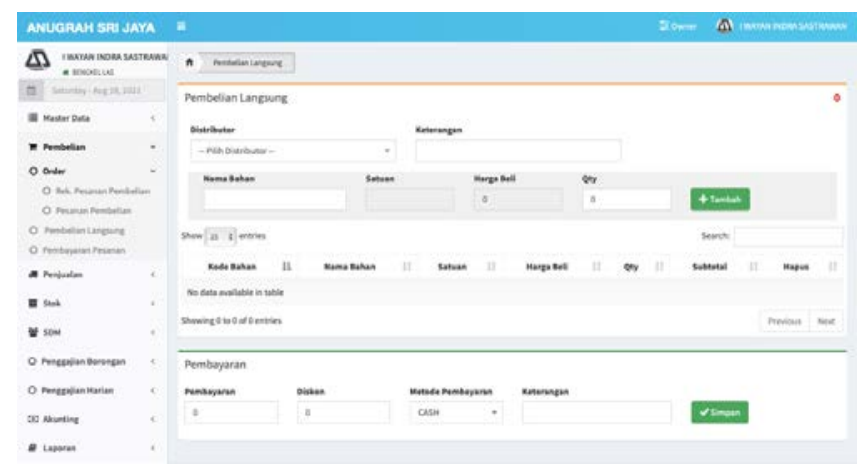

Fig. 6. Purchase Menu Page

\section{Sales Menu Page}

In the sales menu, there are four submenus, including orders, production, payment and direct sales submenus. One of the displays on the sales menu is shown in Figure 7.

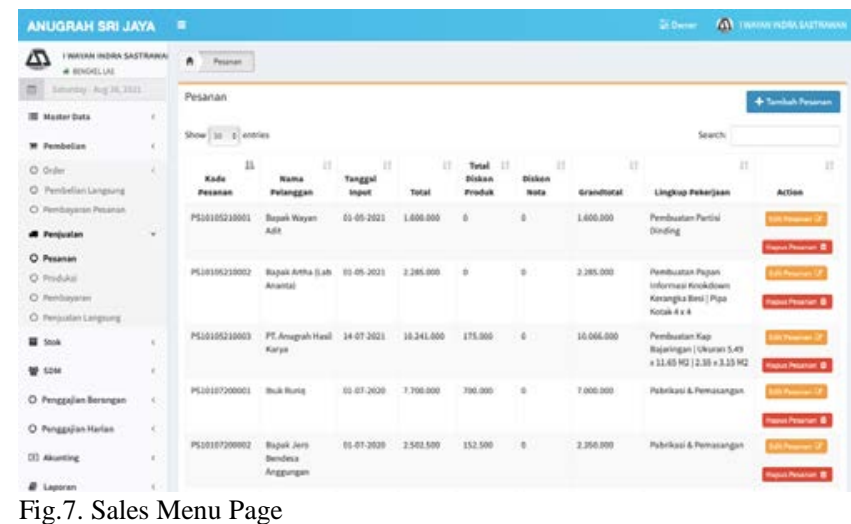

Stock Menu Page

The stock menu is used to manage the stock of existing 
needs in the company. In the stock menu, there are two submenus, including stock taking and material returns. Here is one display on the stock menu, namely the stock taking sub menu in Figure 8.

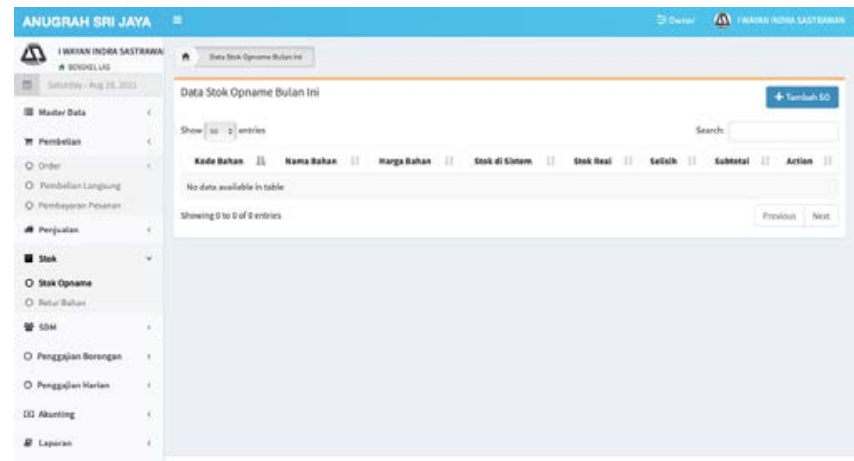

Fig. 8. Stock Menu Page

\section{HR and Payroll Menu Page}

On the HR menu there is a payroll menu which is used for the payroll process for both wholesale and daily employees. Here is one display of the wholesale payroll submenu in Figure 9.

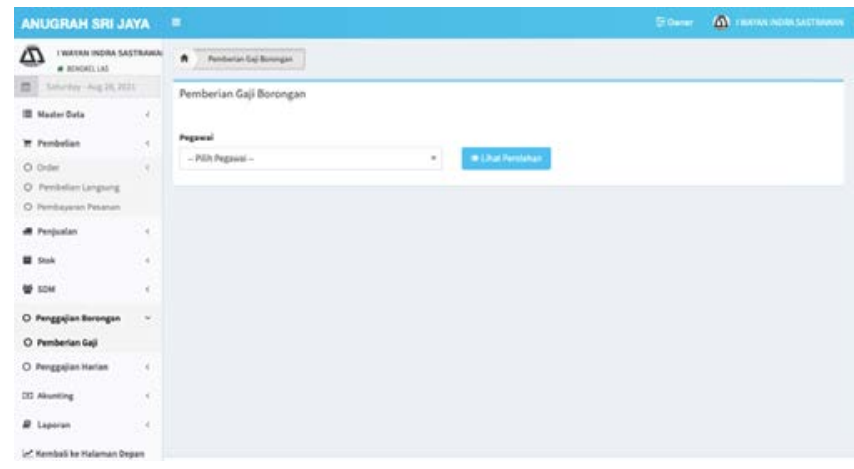

Fig. 9. HR and Payroll Menu Page

\section{Accounting Menu Page}

In the accounting menu, there are seven submenus including assets. Templates for transactions, cash receipts, general journals, cash in. out, profit and loss and balance sheets. This menu is used for all existing financial processes. The following is a display of the sub menu in the accounting menu in Figure 10.

\section{Report Menu Page}

The report menu in this system has 6 sub menus where the owner can view the results of the financial statements of each section such as master data reports, purchase reports, sales reports, stock reports, employee reports, and financial reports. One view of the report is shown in figure 11.

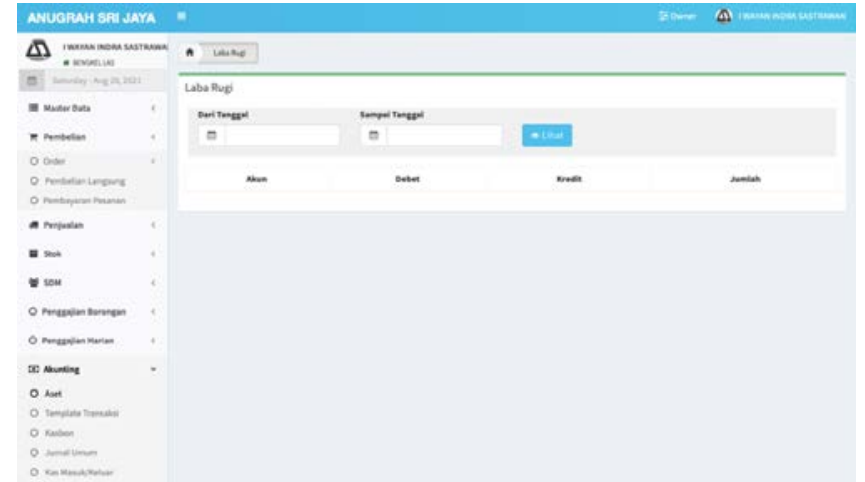

Fig. 10. Accounting Menu Page

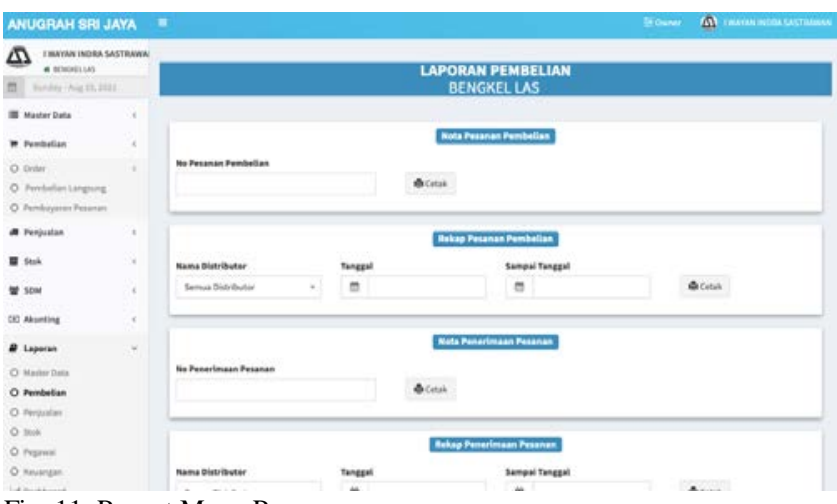

Fig. 11. Report Menu Page

\section{B. System Testing}

System testing was carried out using the Usability Scale (SUS) method. Usability is the level of quality of a system that is easy to learn, easy to use [15]. Usability Scale (SUS generally uses questioning techniques for users in forms such as questionnaires, field observations, SUS to obtain information about the quality of the system created [16]. System Usability Scale (SUS) which consists of 10 statements using a Likert scale 1 to 5. Odd number statements are statements that are positive and even number statements are negative statements [16].

TABLE I

LIST OF QUESTIONNAIRE QUESTIONS

\begin{tabular}{ll}
\hline \hline & \\
\hline 1 &
\end{tabular}


Each question will be given a weight of 0-4. In positive tone statements, the score is calculated by subtracting the weight of each statement. The weight of the statement is reduced by 1 , so it is written xi-1. Meanwhile, to get a score for a negative statement by calculating the weight of the statement minus 5 so that it is written xi-5. Then add up the scores for the positive and negative statements. To get the overall score, the total score is done with 2.5. Based on the SUS score, it can be seen how the level of reusability and acceptance of the display on this accounting information system. The equation for calculating the SUS method is as follows:

Average Score $=\longdiv { \sum _ { i = 1 } ^ { n } x i / N }$

Where:

$\mathrm{xi}=$ respondent's score

$\mathrm{N}=$ number of respondents

Assessment based on 3 categories:

a. Not Acceptable $=$ score $0-50.9$

b. Marginal = score 51-70.9

c. Acceptable $=$ score $71-100$

Of the 5 respondents who are the owners and employees of Anugrah Srijaya, it is always the user who will use this information system, after the SUS score calculation process is carried out, the score is obtained as follows:

Respondent 1: 75

Respondent 2: 80

Respondent 3: 72.5

Respondent 4:70

Respondent 5: 65

The average value obtained from equation (1) is 72.5 . This indicates that the information system is included in the Acceptable category.

SUS scores were analyzed and interpreted using the acceptability, value scale, and adjective rating scales with multiples of 10 . A scale of $1->10$ is categorized as worst imaginable, scores $>10$ - 20 are categorized as awful, scores of 20 - > 30 belongs to a poor rating, a score $>30$ - >50 goes into an ok rating, a scale $>50->70$ goes into a good rating, a scale $>70->80$ goes into an excellent rating, while a scale $>80$ to $>90$ into the best imaginable rating [17] which is shown in the image below:

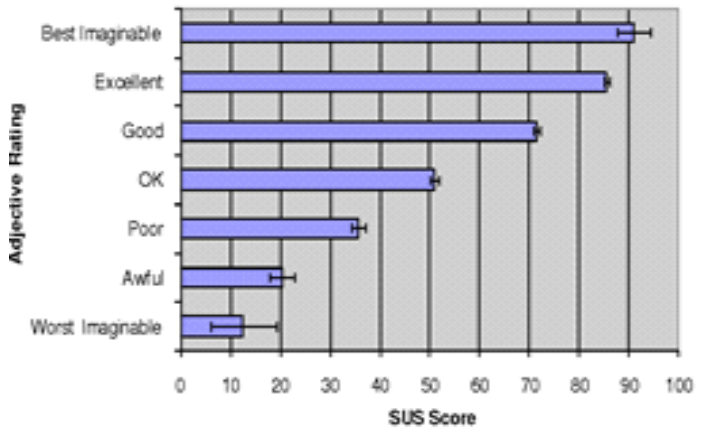

Fig. 12. SUS Score

Based on the SUS Rating based on the acceptance category (Acceptable), it is included in the excellent rating.

\section{CONCLUSION}

The conclusion that can be drawn from this research after testing is that researchers have succeeded in building a webbased accounting information system at Anugrah Srijaya. This system is built using the CodeIgniter (CI) framework with the PHP programming language and for the database storage process using MySQL. Transaction input where transaction data is processed into the form of general journal reports, ledgers, cash flows, profit and loss and balance sheets. The accounting information system that is built is expected to minimize problems that occur in the company such as errors in the calculation process, speed up the process of billing receivables to customers, inventory stock information that can be in accordance with reality and can simplify and speed up the process of searching for data and finding information with the creation of financial reports. systematic. The test in this study uses the System Usability Scale (SUS) test where the test uses a questionnaire as an assessor and the number of responses is 5 respondents where the respondents from this study are business owners and several employees who will later use this system. From the results of the tests carried out, it can be seen that the average score obtained from the calculation of the System Usability Scale (SUS) is 74.5. Based on the results of the average score, this system can be said to be in the category of acceptance (Acceptable) and on the adjective rating scale, the information system built is rated as excellent.

\section{ACKNOWLEDGMENT}

Thank you to the leadership of the company Anugrah Sri Jaya and all those who have helped carry out this research 


\section{REFERENCES}

[1] I. R. A. Putra and M. Megawati, "Rancang Bangun Sistem Informasi Akuntansi Berbasis Web (Studi Kasus: PT. KALBER REKSA ABADI)," J. Sains, Teknol. dan Ind., vol. 15, no. 2, p. 98, 2018.

[2] A. Hakim, "Model Struktural Hubungan Teknologi Informasi, Kualitas Informasi dan Kinerja Manajerial Industri Kreatif Percetakan Digital,” J. Mix, vol. 17, no. 1, pp. 1-13, 2016.

[3] M. Hasbiyalloh and D. A. Jakaria, “Aplikasi Penjualan Barang Perlengkapan Handphone di Zildan Cell Singaparna Kabupaten Tasikmalaya,” Jumantaka, vol. 1, no. 1, pp. 61-70, 2018.

[4] W. Adi Prabowo and C. Wiguna, "Sistem Informasi UMKM Bengkel Berbasis Web Menggunakan Metode SCRUM,” J. Media Inform. Budidarma, vol. 5, no. 1, pp. 149-156, 2021.

[5] D. Prakasita N and M. A. Nugroho, "Perancangan Sistem Informasi Akuntansi Penjualan Dan Persediaan Di Central Steak and Coffee Boyolali,” Nominal, Barom. Ris. Akunt. dan Manaj., vol. 7, no. 1, pp. 69-81, 2018.

[6] Musmini, "Sistem Informasi Akuntansi Untuk Menunjang Pemberdayaan Pengelolaan Usaha Kecil," Vokasi J. Ris. Akunt., vol. 2, no. 1, pp. 62-81, 2016.

[7] N. S. Anggraeni and R. Ujiandari, "Pemanfaatan Aplikasi Akuntansi Zahir Accounting Untuk Menyelesaikan Transaksi Keuangan Pada PT.Wahana Baru Kreasindo,” Idealis, vol. 3, no. 1, pp. 350-355, 2020.

[8] D. S. Purnia, A. Rifai, and S. Rahmatullah, "Penerapan Metode Waterfall dalam Perancangan Sistem Informasi Aplikasi Bantuan Sosial Berbasis Android,” Semin. Nas. Sains dan Teknol. 2019, pp. 1-7, 2019.

[9] L. Setiyani, Y. Rostiani, and T. Ratnasari, "Analisis Kebutuhan Fungsional Sistem Informasi Persediaan Barang Perusahaan General Trading (Studi Kasus: PT. Amco Multitech),” Owner, vol. 4, no. 1, p. 288, 2020.

[10] N. A. Wibisono, "Analisis dan Perancangan Sistem Informasi Toko untuk Mencapai Keunggulan Kompetitif ( Studi pada Toko Sakinah Motor Kabupaten Sukoharjo )," vol. 47, no. 2, pp. 83-93, 2017.

[11] D. Saputra, "Modul Pembelajaran Analisa \& Perancangan Sistem Informasi," J. Chem. Inf. Model., vol. 53, no. 9, pp. 1689-1699, 2017.

[12] A. K. Putri et al., "Pengembangan Sistem Informasi Tracer Study Berbasis User Centered Design ( UCD ) Menggunakan Framework Laravel,” vol. 5, pp. 10271037, 2021.

[13] E. Kaban, K. C. Brata, and A. H. Brata, "Evaluasi Usability Menggunakan Metode System Usability Scale (SUS) Dan Discovery Prototyping Pada Aplikasi PLN Mobile (Studi Kasus Pt. PLN),” J. Pengemb. Teknol. Inf. dan Ilmu Komputer; Vol 4 No 10, vol. 4, no. 10, pp. 3281-3290, 2020.

[14] A. Sidik, "Penggunaan System Usability Scale (SUS) Sebagai Evaluasi Website Berita Mobile,” Technol. J. Ilm., vol. 9, no. 2, p. 83, 2018.

[15] Fachruddin, M. R. Pahlevi, M. Ismail, E. Rasywir, and Y. Pratama, “Analisis Usability Pada Implementasi Sistem Pengelolaan Keuangan Masjid Menggunakan USE Questionnaire,” J. Media Inform. Budidarma, vol. 4, pp. 1216-1224, 2020.

[16] Hilda Rachmi and Siti Nurwahyuni, "Pengujian Usability Lokamedia Website Menggunakan System Usability Scale,” Al-Khidmah, vol. 1, no. 1, pp. 86-92, 2018.
Abdullah Izzul Islam, A. Jamaludin, and N. Heryana, "Sistem Pendukung Keputusan Kelayakan Klaim Asuransi Menggunakan Metode AHP,” J. Inform. Polinema, vol. 7, no. 2, pp. 115-122, 2021. 